\title{
The Toxicity and Polymorphism of $\beta$-Amyloid Oligomers
}

\author{
Ya-ru Huang ${ }^{1,2}$ and Rui-tian Liu $1, *$ (D) \\ 1 State Key Laboratory of Biochemical Engineering, Institute of Process Engineering, \\ Chinese Academy of Sciences, Beijing 100190, China; yrhuang@ipe.ac.cn \\ 2 School of Chemical Engineering, University of Chinese Academy of Sciences, Beijing 100049, China \\ * Correspondence: rtliu@ipe.ac.cn; Tel.: +86-010-8254-5017
}

Received: 22 May 2020; Accepted: 20 June 2020; Published: 24 June 2020

\begin{abstract}
It is widely accepted that $\beta$-amyloid oligomers (A $\beta$ os) play a key role in the progression of Alzheimer's disease (AD) by inducing neuron damage and cognitive impairment, but $\mathrm{A} \beta$ os are highly heterogeneous in their size, structure and cytotoxicity, making the corresponding studies tough to carry out. Nevertheless, a number of studies have recently made remarkable progress in the describing the characteristics and pathogenicity of $A \beta$ os. We here review the mechanisms by which $\mathrm{A} \beta$ os exert their neuropathogenesis for $\mathrm{AD}$ progression, including receptor binding, cell membrane destruction, mitochondrial damage, $\mathrm{Ca}^{2+}$ homeostasis dysregulation and tau pathological induction. We also summarize the characteristics and pathogenicity such as the size, morphology and cytotoxicity of dimers, trimers, $A \beta^{*} 56$ and spherical oligomers, and suggest that $A \beta$ os may play a different role at different phases of $\mathrm{AD}$ pathogenesis, resulting in differential consequences on neuronal synaptotoxicity and survival. It is warranted to investigate the temporal sequence of $A \beta$ os in $\mathrm{AD}$ human brain and examine the relationship between different $\mathrm{A} \beta$ os and cognitive impairment.
\end{abstract}

Keywords: $\beta$-amyloid oligomers; Alzheimer's disease; polymorphism; toxicity; aggregation

\section{Introduction}

Alzheimer disease (AD) is a chronic neurodegenerative disease which imposes a heavy burden on families and society [1]. The neuropathological profiles of $\mathrm{AD}$ are mainly manifested as the extracellular senile plaques aggregated by $\beta$-amyloid $(A \beta)$, and the formation of intracellular neurofibrillary tangles aggregated by hyperphosphorylated tau protein [2]. A $\beta$ has normal physiological function and maintains a low concentration in vivo [3], however, factors such as aging, oxidative stress and gene mutation cause the disruption of $A \beta$ homeostasis, resulting in $A \beta$ accumulation and aggregation, formation of oligomers and fibers, and plaque deposits in brains [4]. Heavy evidence has confirmed that $A \beta$ oligomers ( $A \beta O s)$ are the most neurotoxic aggregates and play a critical role in the occurrence and development of $\mathrm{AD}$ by causing functional neuron death, cognitive damage, and dementia. In recent years, $\mathrm{A} \beta$ os have been extracted and characterized by various methods, and remarkable progress has been made in the mechanism of pathogenesis. In this review, we introduce the neurotoxic mechanisms of $A \beta o s$, and review the properties of $A \beta$ os with different size, conformation and neurotoxicity.

\section{The Formation of $\mathrm{A} \beta \mathbf{o s}$}

$A \beta$ is produced principally in neuronal endosomes by hydrolysis of amyloid precursor protein (APP) with $\beta$-secretase and $\gamma$-secretase [5,6], and its release is modulated by synaptic activity [7]. Studies identified that under normal physiological conditions, $A \beta$ can inhibit the excessive activation of synapses and reduce the production of synaptic excitotoxicity [8-10]. Moreover, $A \beta$ may be an antibacterial peptide in CNS innate immunity, which protects the body from infections, and A $\beta$ 
aggregation may be a protective response against infection [11,12]. But under the pathological condition, the production of $A \beta$ increases or the clearance is inhibited, leading to $A \beta$ abnormal accumulation and aggregation to form $\beta$-sheet-rich conformations [13,14].

Oligomers are soluble polymers assembled by monomers, some of which are intermediates in fibril generation. Oligomers have different molecular weights and conformations, which results in various oligomeric properties. There is plenty of evidence that $A \beta$ os contribute to the development of $\mathrm{AD}$, therefore, clarifying the molecular events related to the aggregation of $\mathrm{A} \beta$ monomers into toxic $A \beta$ os is the key to understand the pathological mechanism of $A D$. $A \beta$ aggregates can formed by the assembly of two or more monomers through fibril-independent pathway (primary nucleation) or fibril-dependent mechanism (secondary nucleation), in which $A \beta$ monomers aggregate on the surface of fibrils in a prion-like manner $[15,16]$. Monitoring the kinetics of $A \beta$ aggregation in vitro with synthetic $A \beta$, the process is typically divided into three phases: an initial lag phase, a subsequent growth phase and a final stationary phase [17] (Figure 1).

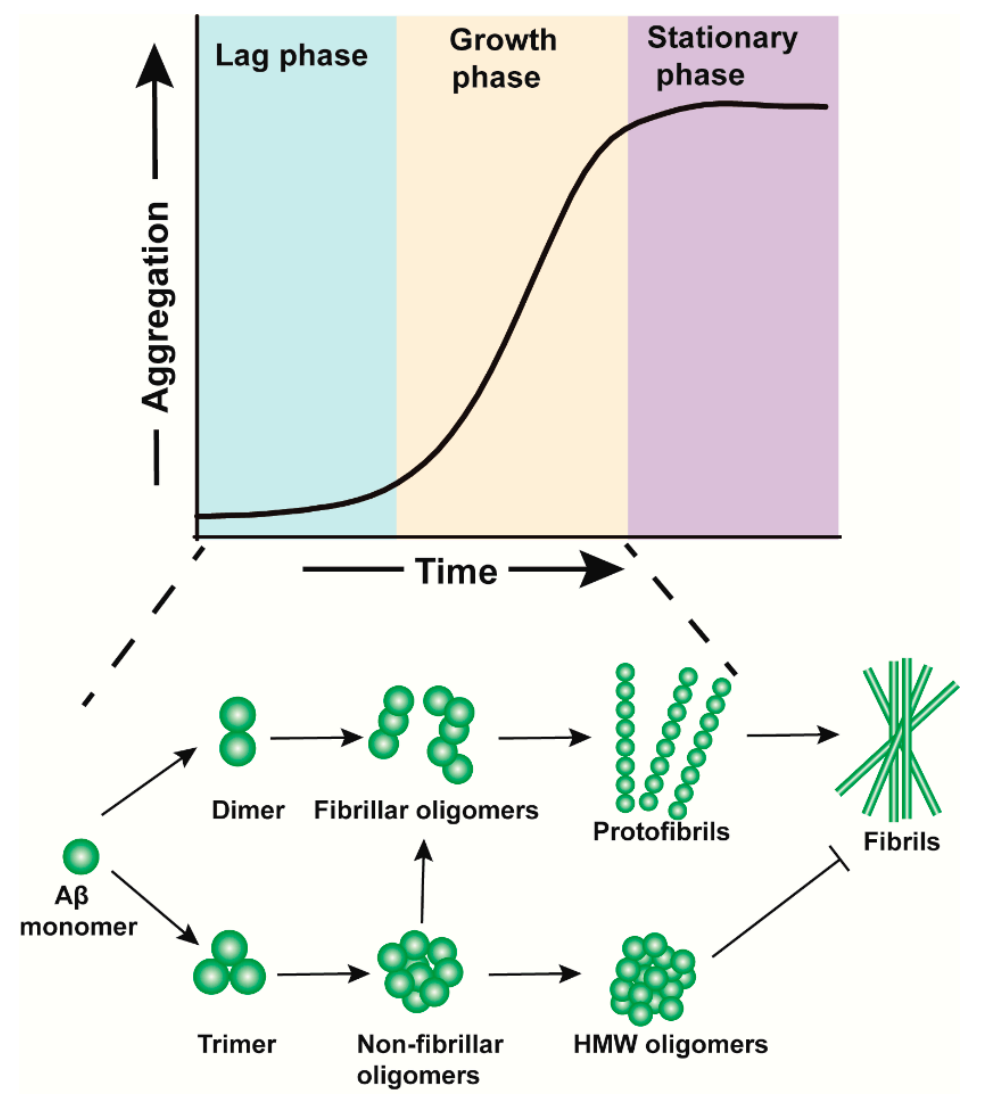

Figure 1. Schematic representation of the process of $\beta$-amyloid $(A \beta)$ aggregation. There are three phases from $A \beta$ monomers to mature fibrils: an initial lag phase, a subsequent growth phase and a final stationary phase. $\beta$-amyloid oligomers (A $\beta$ os), necessary intermediates in fibril generation, mainly exist in lag phase and growth phase. Some A $\beta$ os, termed as fibrillar oligomers, can quickly form protofibrils and mature fibrils through fibril-forming pathway, in which the first step corresponds to the formation of $A \beta$ dimers, whereas others such as $A \beta$ trimers or globulomers, termed as non-fibrillar oligomers, are structurally distinct from fibrillar aggregates, and they contribute to the formation of fibrils through a structural conversion to become fibrillar oligomers.

$A \beta$ os are intermediates of $A \beta$ aggregation, which are formed in lag phase and growth phase and reveal a range of intermediates with different size, morphology and conformation $[18,19]$. Some oligomeric $A \beta$ intermediates such as $A \beta$ dimers, denoted fibrillar oligomers, enter the fibril-forming pathway to form fibrils, whereas others such as $A \beta$ trimers or globulomers pool 
as stable non-fibrillar oligomers [20,21]. Latest study showed that non-fibrillar oligomers could convert into fibrillar oligomers but the rate of oligomer conversion was very slow [16]. A $\beta$ os were first detected in 1994. Researchers extracted the soluble $A \beta$ component in the brain by a non-denaturing method, and found that $A \beta$ level in the soluble component was related to the severity of AD [22,23]. The discovery of $\mathrm{A} \beta$ os and the inconsistency between cognition and brain plaques shifted the focus of $\mathrm{A} \beta$ research from fibers to oligomers.

\section{The Neurotoxicological Mechanisms of Aßos}

The "amyloid cascade hypothesis", proposed in 1992, suggests that A $\beta$ deposition is the first step in the pathological development of $\mathrm{AD}$, which then leads to tau pathologies, synaptic dysfunction, neuron loss and dementia [24]. Subsequently, due to the significant toxicity of $A \beta O s$, and the close relationship between oligomers and cognition and memory, the hypothesis was revised to "A $\mathrm{\beta}$ os cascade hypothesis" [25], which suggests that soluble A $\beta$ os directly cause neural signal dysfunction, induce neuronal apoptosis, and inhibit synaptic long-term potentiation (LTP). Multiple studies have shown that $\mathrm{A} \beta$ os exert neurotoxic effects through multiple mechanisms, such as receptor binding, mitochondrial dysfunction, $\mathrm{Ca}^{2+}$ homeostasis dysregulation and tau pathologies (Figure 2).

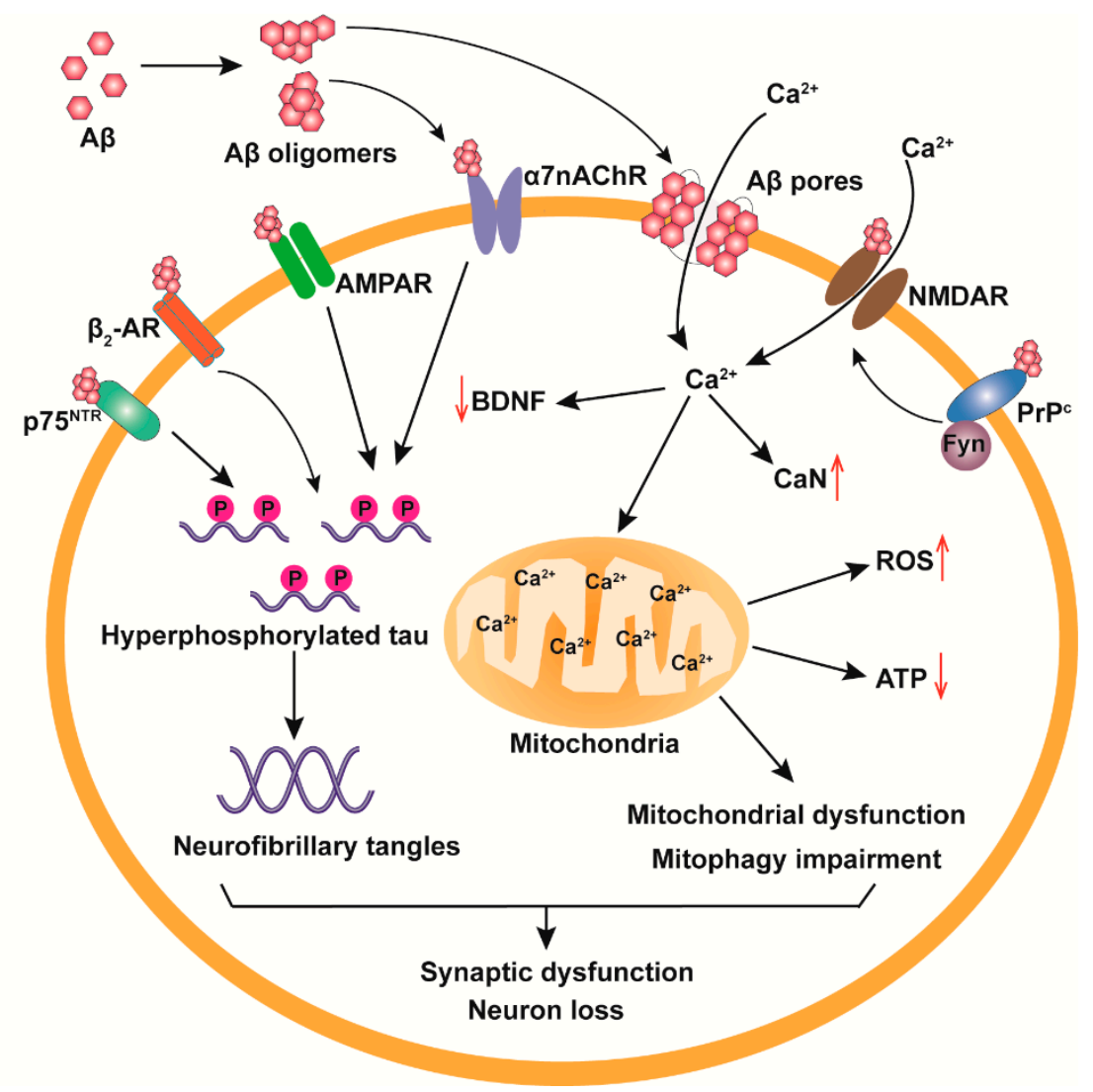

Figure 2. Schematic of the neurotoxicological mechanisms of $A \beta o s$. A $\beta$ os, mainly produced extracellularly, can bind to multiple receptors on the surface of neuronal membrane and interfere with the normal signaling pathways of the receptors, and they can also directly interact with membrane to form pore structure, leading to the change of membrane integrity and permeability. These two effects of $\mathrm{A} \beta$ os on cell membrane can further induce $\mathrm{Ca}^{2+}$ homeostasis dysregulation, mitochondrial damage, reactive oxygen species (ROS) generation, reduction of ATP level and abnormal tau phosphorylation, resulting in synaptic dysfunction, neuron loss and impairment of long-term potentiation (LTP). 


\subsection{Receptor-Mediated Neurotoxicity of ABos}

A $\beta$ os can bind to the receptors on the surface of neurons, alter downstream signaling pathways, and cause cell death ultimately. There are more than 20 types of receptors recognized by $A \beta$ os such as cellular prion protein $\left(\mathrm{PrP}^{\mathrm{c}}\right)$, glutamate receptors, $\beta_{2}$-adrenergic receptor $\left(\beta_{2}-\mathrm{AR}\right)$, p75 neurotrophin receptor $\left(\mathrm{p} 75^{\mathrm{NTR}}\right)$ and $\alpha 7$-nicotinic acetylcholine receptor $(\alpha 7 \mathrm{nAChR})$ [26]. Under normal physiological conditions, $\operatorname{PrP}^{\mathrm{C}}$ is an important protein regulating $\mathrm{A} \beta$ metabolism in vivo by inhibiting $\beta$-secretase activity and decreasing the production of APP intracellular domain (AICD) [27]. However, A $\beta$ os bind to $\operatorname{PrP}^{\mathrm{C}}$ and affect $\mathrm{PrP}^{\mathrm{C}}$ normal physiological functions in $\mathrm{AD}$ brains $[28,29]$. A $\beta$ os can directly interact with $\mathrm{PrP}^{\mathrm{c}}$, impair LTP and cause neuritic dystrophy by activating Fyn tyrosine kinase and causing phosphorylation of $N$-methyl-D-aspartate receptor (NMDAR), but when the expression of $\operatorname{PrP}$ is removed, these adverse effects are deprived [30-32].

Aßos can impair the activity of glutamate receptors to interfere with synaptic plasticity [33]. NMDAR is a glutamate receptor, which has ion channel activity, and plays a critical role in regulating synapse formation and synaptic plasticity [34]. Some studies have indicated that Aßos disturbed NMDAR activity and impaired NMDAR-dependent signaling pathway, leading to synaptic loss and the decrease of spinal density [7,35]. In addition, A $\beta$ os disturb the NMDAR-mediated postsynaptic $\mathrm{Ca}^{2+}$ signaling by affecting the function of NMDAR and altering the availability of extracellular glutamate, which causes LTP impairment [36]. $\alpha$-Amino-3-hydroxy-5-methyl-4-isoxazolepropionic acid receptor (AMPAR) is another glutamate receptor containing four subunits GluA1-A4, which participates in modulation of synaptic plasticity and homeostasis [37]. Aßos induce the reduction of AMPAR level by accelerating the degradation, and increase AMPAR ubiquitination, resulting in the loss of AMPAR activity and suppression of synaptic transmission [38]. Moreover, A $\beta$ os cause tau hyperphosphorylation and abnormal accumulation in dendritic spines, which in turn deficits the Aßos-mediated AMPAR signaling pathway, forming a vicious cycle [39].

$\beta_{2}$-AR, expressed in hippocampus and cortex, is required for learning and memory. Soluble $A \beta 42$ can bind to the extracellular $\mathrm{N}$ terminus of $\beta_{2}$-AR and then interfere with AMPAR activity by inducing G-protein/cAMP/protein kinase A (PKA) signaling, which may cause excessive $\mathrm{Ca}^{2+}$ to flow into neurons and induce excitatory neurotoxicity, leading to overactivity of neurons and loss of dendritic spines ultimately [40,41]. Research has found that low molecular weight (MW) A $\beta$ os led to the decrease of $\beta_{2}$-AR level and impairment of hippocampal LTP [42]. In addition, $\beta_{2}$-AR can promote tau protein phosphorylation through the $\beta_{2}$-AR-PKA-JNK signaling pathway [40]. These results demonstrate that $\beta_{2}$-AR may have an important effect on AD pathogenesis.

p $75^{\mathrm{NTR}}$ is a transmembrane protein, which participates in Aßos-mediated neurodegenerative signals. In cholinergic basal forebrain ( $\mathrm{CBF}$ ) neurons, A $\beta$ os bind to cysteine-rich repeat domains 2 and 4, the extracellular domain of $p 75^{\mathrm{NTR}}$ [43], to mediate tau pathology, synaptic disorder and promote the degradation of neurons [44]. Removal of $\mathrm{p} 75^{\mathrm{NTR}}$ expression from cBF neurons causes the improvement of $A \beta$ plaque deposition and cognitive impairment and attenuates the tau pathologies in $\mathrm{AD}$ transgenic mice $[45,46]$. Moreover, after binding to $\mathrm{A} \beta, \mathrm{p} 75^{\mathrm{NTR}}$ can regulate $\mathrm{A} \beta$ production by interacting with beta-site amyloid precursor protein cleaving enzyme-1 (BACE1) and enhancing the colocalization and internalization of BACE1 and APP [47], besides, it also has an impact on the clearance and deposition of $A \beta$ [48]. The latest study identified that $p 75^{\mathrm{NTR}}$ influenced the effect of $\mathrm{A} \beta 42$ on the L-type $\mathrm{Ca}^{2+}$ channel current by disturbing the function of voltage-dependent $\mathrm{Ca}^{2+}$ channels, which can be eliminated after decreasing the expression of p75 ${ }^{\mathrm{NTR}}$ [49].

$\mathrm{A} \beta$ os have high affinity with $\alpha 7 \mathrm{nAChR}$ [50], and lead to the internalization of the $\mathrm{A} \beta-\alpha 7 \mathrm{nAChR}$ complex, which induces plaque formation and promotes neurotoxicity [51,52]. However, some studies have found that $\alpha 7 \mathrm{nAChR}$ had a neuroprotective effect. Activation of $\alpha 7 \mathrm{nAChR}$ inhibited neuronal $\gamma$-secretase activity, and $\mathrm{p} 38$ or JNK activity, both of which contribute to the alleviation of $A \beta$ burden and $\mathrm{A} \beta$-induced memory deficits [53-55].

In addition to the above receptors, $\mathrm{A} \beta$ os can also bind to paired immunoglobulin-like receptor $\mathrm{B}$ (PirB) [56,57], EphB2 receptor [58,59], metabotropic glutamate receptor 5 (mGluR5) $[60,61]$ and other 
receptors to exert neurotoxicity. However, it is not explicit that which receptor has the highest affinity to $A \beta$ os in brains or induces deadly damage to neurons. A $\beta$ os are highly heterogeneous with multiple sizes and conformations, and different oligomers may bind to different receptors. The studies to determine the binding of certain $A \beta$ oligomer to its receptors to exert specific toxicity are warranted.

\subsection{Cell Membrane Destruction}

A $\beta$ os rather than monomers and fibers can directly act on the cell membrane to form channels, and destroy membrane integrity and permeability [62-64]. High-MW aggregates elevate the intracellular $\mathrm{Ca}^{2+}$ level by increasing the membrane lipid peroxidation reaction and changing the membrane structure and function, resulting in the suppression of LTP and neuronal death [65]. On the other hand, after binding to the $\beta$-sheets of the $N$-terminal residues of $A \beta$ os, lipid bilayers stabilize the structure of $\mathrm{A} \beta$ os and accelerate fiber formation [66]. The molecular docking results showed that the U-shaped oligomers inserted into the membrane and formed ion-permeable pores [67], which is consistent with the report that $\mathrm{A} \beta$ can insert into lipid bilayers and assemble into a $\beta$-barrel pore under optimized detergent micelle conditions [68]. A $\beta$ os can also interact with lipids and cholesterol in the membrane to exert their toxicity [69-73]. For example, A $\beta$ os strongly bind to GM1 ganglioside located at the external face of the cell membrane to promote LTP impairment, which requires the existence of sialic acid residues of GM1 [71]. Moreover, GM1 not only affects A $\beta$ os-mediated perforation of cell membrane [73], but also influences the aggregation and the secondary structure of A $\beta$ os $[70,74]$. The effect of cholesterol on the toxicity of $A \beta$ os to membrane is controversial. Cholesterol can change the structures of $A \beta$ os and facilitate the interaction between $A \beta$ and the membrane, on the other hand, cholesterol increases the membrane rigidity and has a protective effect against $\mathrm{A} \beta$ os-mediated damage $[69,72]$.

\subsection{Mitochondrial Damage and $\mathrm{Ca}^{2+}$ Homeostasis Dysregulation}

A $\beta$ os increase $\mathrm{Ca}^{2+}$ influx and cause intracellular $\mathrm{Ca}^{2+}$ homeostasis dysregulation by binding to receptors on neuronal membranes and disrupting the structure and permeability of cell membranes [75,76]. Increased intracellular $\mathrm{Ca}^{2+}$ induces the activization of the $\mathrm{Ca}^{2+} /$ calmodulin-dependent phosphatase calcineurin (CaN) and glycogen synthase kinase $3 \beta(\mathrm{GSK} 3 \beta)$, which can induce hyperphosphorylation of tau, impair the transport of brain-derived neurotrophic factor (BDNF) and cause transport dysregulation in both axons and dendrites [77]. Moreover, the destruction of intracellular $\mathrm{Ca}^{2+}$ homeostasis causes mitochondrial $\mathrm{Ca}^{2+}$ overload and mitochondrial dysfunction $[78,79]$. The mitochondrial $\mathrm{Ca}^{2+}$ dysregulation then directly induces superoxide generation, ATP utilization and neuron death by increasing the opening of mitochondrial permeability transition pores (MPTP) and activization of $\mathrm{Ca}^{2+}$-dependent proteases (calpains) [80,81]. In addition, Aßos elevate parkin level in mitochondria and induce mitochondrial dysfunction, but these adverse effects are eliminated when parkin is overexpressed [82]. Mitophagy is an essential cell activity to degrade and remove damaged mitochondria or excess mitochondria, which participates in the adjustment of the functional integrity of the mitochondrial network and cell survival [83]. Mitochondrial $\mathrm{Ca}^{2+}$ dysregulation also interferes with mitophagy [84], which further aggravates the generation of $A \beta$ aggregates and $\mathrm{AD}$ pathological development, forming a vicious cycle between $\mathrm{A} \beta$ os and mitochondrial disability $[85,86]$.

\subsection{Tau Pathologies}

$\mathrm{A} \beta$ and tau are two main pathogenic factors in the pathogenesis of $\mathrm{AD}$. Although there is no clear answer which is the key factor responsible for the onset of $\mathrm{AD}$, some progress in our understanding of the relationship between $A \beta$ and tau has been achieved in recent years. Longitudinal evaluations of $A \beta$ and tau PET imaging have indicated that $A \beta$ deposition first appears in the cortex, at least 10-20 years earlier than clinical symptoms, which precedes the development of tau lesions, neuron death and hippocampal volume loss [87-89]. The rate of $A \beta$ accumulation can predict the occurrence of tau 
aggregation, and the rate of tau accumulation is associated with decreased global cognition, which can predict the severity of cognitive impairment [90]. Examining the interaction between $A \beta$ and tau indicated that $\mathrm{A} \beta$ deposition may be used as seeds to facilitate the pathological development of tau by creating a unique environment [91-93], which is coincident with the research that tau aggregates could not widely spread in the absence of $A \beta$ deposition [94]. In addition, $A \beta$ os bind to $\alpha 2 A A R$ receptors on the surface of neurons, thereby activate GSK3 $\beta$ and promote tau hyperphosphorylation. The required concentration of $\mathrm{A} \beta$ os to promote tau hyperphosphorylation through this pathway is much lower than that to play direct effects [95]. However, latest study showed that tau burden first emerged in entorhinal cortex and hippocampus of $\mathrm{AD}$ patients, which preceded the global cortical $\mathrm{A} \beta$ by about 3 years [96].

\section{The Polymorphism of $A \beta$ os}

A $\beta$ os are highly heterogeneous and exhibit diversities in size, conformation, aggregation mode, toxicity and appearance time in the brain. In order to accurately explore the characteristics of different $A \beta$ os, the first step is to separate oligomers with different sizes or conformations. Currently, some approaches such as centrifugation and size exclusion chromatography (SEC) can separate oligomers according to molecular size but cannot distinguish conformations. Multiple Aßos-specific antibodies such as A11, OC, as well as W20, NAbs-A $\beta$ o, prepared in our laboratory, have been confirmed to recognize the advanced conformation of A $\beta$ os [97-100], which can be used to extract A $\beta$ os with different conformations. Separated by these strategies, the properties of different A $\beta$ os can be studied detailly. Next, we review the characteristics and toxicity of several main types of oligomers, including dimers, trimers, $A \beta * 56$, and spherical oligomers (Table 1).

Table 1. The characteristics and toxicity of several A $\beta$ oligomers.

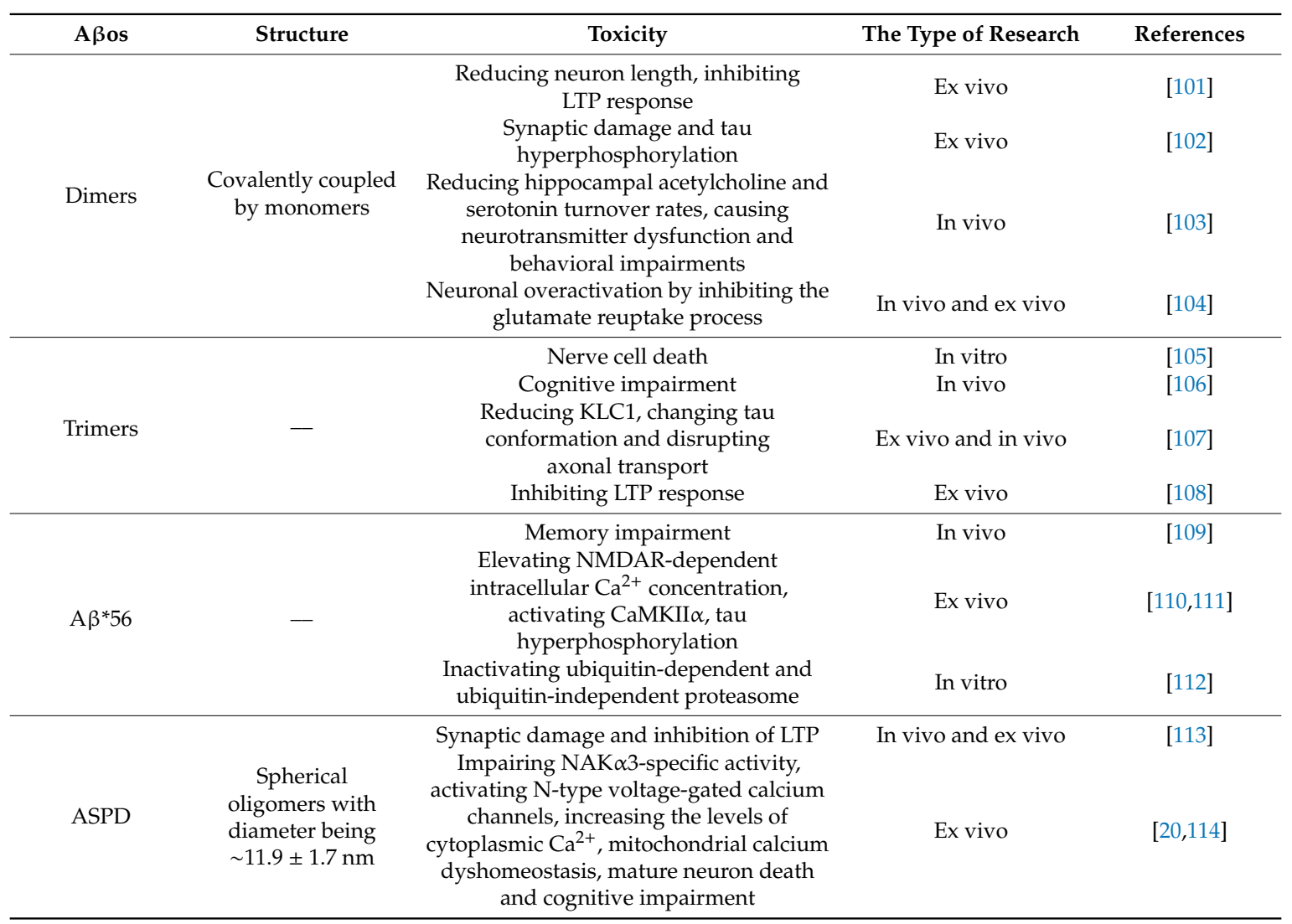


Table 1. Cont.

\begin{tabular}{|c|c|c|c|c|}
\hline $\mathrm{A} \beta \mathrm{os}$ & Structure & Toxicity & The Type of Research & References \\
\hline \multirow{4}{*}{ ADDLs } & \multirow{4}{*}{$\begin{array}{l}\text { Small sphere with a } \\
\text { diameter of } 5-6 \mathrm{~nm}\end{array}$} & Abnormal autophagy of neurons & Ex vivo & [115] \\
\hline & & $\begin{array}{l}\text { Reducing the level of insulin receptor and } \\
\text { disrupting normal insulin signaling }\end{array}$ & In vitro and in vivo & {$[116,117]$} \\
\hline & & $\begin{array}{l}\text { Inducing the degradation of } \mathrm{EPhB} 2 \\
\text { receptor and the phosphorylation of } \\
\text { NMDAR, impairing synaptic plasticity }\end{array}$ & Ex vivo and in vivo & [118] \\
\hline & & $\begin{array}{c}\text { Abnormal localization of tau to dendrites } \\
\text { by activating tyrosine kinase Fyn }\end{array}$ & Ex vivo and in vivo & {$[119,120]$} \\
\hline
\end{tabular}

\subsection{A Dimers}

$A \beta$ dimers are the smallest $A \beta$ aggregates, and they have three characteristics: high levels in the brains of AD patients and transgenic mice [121-124], stable in SDS and strong denaturants $[101,104,122,125,126]$, and significant neurotoxicity [101-104]. When treated with 6.8M guanidine thiocyanate, the soluble $A \beta$ aggregates and insoluble $A \beta$ plaques in $A D$ brains are dispersed into two bands in SDS gel electrophoresis (SDS-PAGE), such as A $\beta$ monomers and dimers $[104,124,125]$. It is proposed that $A \beta$ dimers are formed by cross-link via tyrosine acid residue phenol coupling (DiY) and enzymatic coupling $(\mathrm{QK})$ between glutamine and tyrosine residues, resulting in the resistance of dimers to the strong denaturants $[125,126]$. The latest study showed that $A \beta$ dimers derived from $A D$ human brains were composed of multiple $A \beta$ monomers with different lengths, and these different monomers were covalently coupled at the ASP1 and Glu22 sites to form stable dimers [101]. However, it is unclear whether the toxicities of the dimers formed through different cross-linking sites are different.

It is generally considered that $\mathrm{A} \beta$ dimers may be the basic constituent unit of fibers or oligomers. In Tg2576 and J20 model mice, $\mathrm{A} \beta$ dimers were detected after the age of 10 months, in which a large number of plaque deposits appeared in the cortex, indicating that there may be some connections between $A \beta$ dimers and fibers [122,127]. Moreover, $A \beta$ dimers are generally observed in AD patients over 60 years old. The level of $A \beta$ dimers subsequently increases sharply, which shows the positive correlation between dimers and plaque in the brains [110]. In addition, soluble $A \beta$ os in the brain extracts of AD patients were broken down into two molecules of 6.1-7.9 $\mathrm{kDa}$ and 3.5-4.5 $\mathrm{kDa}$, when treated with strong denaturants. It is thus speculated that $A \beta$ dimers may also be the basic unit of $A \beta$ os [124].

Adding brain-derived $A \beta$ dimers to primary neurons can reduce the length of neurons [101], trigger synaptic damage and neuron death, inhibit LTP response and induce tau hyperphosphorylation [102]. In tgDimer mouse, $A \beta$ dimers contribute to the reduction of hippocampal acetylcholine and serotonin turnover rates, resulting in neurotransmitter dysfunction and behavioral impairments [103]. The latest study identified that brain-derived $A \beta$ dimers caused neuronal overactivation by inhibiting the glutamate reuptake process. This process occurs earlier than clinical symptoms and plaque formation [104], indicating that $\mathrm{A} \beta$ dimers may contribute to the early development of AD.

\subsection{A $\beta$ Trimers}

Although there is no obvious correlation between the trimers and plaque deposits, $A \beta$ trimers are considered to be an aggregation unit of multiple $A \beta$ os such as hexamers and dodecamers [128]. Studies have shown that $A \beta * 56$ is a type of $A \beta$ os assembled by trimers [109] and the first step of amylospheroids (ASPD) formation is to from trimers [20]. Moreover, $A \beta$ trimers are the earliest A $\beta$ aggregates in the brains of AD human and transgenic mice. In the primary cortical neurons of $\mathrm{Tg} 2576$ mice, monomers and trimers can be detected before dimers, indicating that trimers may be produced at the early stage. Further research suggested that $A \beta$ trimers first appeared in the embryonic stage of Tg2576 mice, then increased steadily with aging, and existed throughout life [109]. Consistent with AD 
animal models, in human brain, the trimers exist since childhood, and their levels gradually increase with age, but there is no significant correlation between trimers and plaque deposits [110].

The toxicity of $A \beta$ trimers is currently controversial. It was found that trimers and tetramers prepared by PICUP aggregation had prominent toxicity to neurons, but the toxicity of dimers was very weak [105]. Moreover, reducing the amount of A $\beta$ trimers in the brain of APP/PS1 mice significantly alleviated the cognitive impairment [106]. When the cultured primary neurons were treated with $A \beta$ trimers isolated from brain tissues of AD patients, trimers induced the change of tau conformation and caused the disruption of axonal transport, both of which were associated with reduction of the kinesin-1 light chain (KLC1) [107]. However, some studies argued that A $\beta$ trimers acted only as a fundamental assembly unit for toxic assemblies rather than a toxic element. They found that the trimers isolated from 7PA2 cells or AD mouse brains significantly inhibited the LTP response, but the toxicity was smaller than homodimers and $A \beta^{*} 56[108,129]$. In addition, there is no clear relationship between $\mathrm{A} \beta$ trimers and the cognitive ability of $\mathrm{AD}$ mice [109], and the connection between trimers and hyperphosphorylation of tau protein in the brain of AD patients is also ambiguous [110].

\section{3. $A \beta^{* 56}$}

$A \beta * 56$, first detected in Tg2576 mice, is consistent with the occurrence and development trend of cognitive impairment in mice [109]. Some studies have also reported the appearance of $A \beta * 56$ in other AD transgenic mouse models, such as J20 mice [127,130], Arc6/48 mice [130], and 3xTgAD mice [131]. In AD human brains, the level of $A \beta * 56$ is negligible in children and adolescents, but the level rises above baseline and then steadily rises after the age of 40 [110]. $A \beta * 56$ can be recognized by oligomer-specific antibody A11, but not by fiber-specific antibody OC, indicating that $A \beta * 56$ is a non-fibrous $A \beta$ aggregate. Moreover, in brains of $A D$ transgenic mice, $A \beta * 56$ mainly locates on the plaque free tissue and halo, but not plaque core, suggesting that it may have a greater effect on cognitive impairment than other $A \beta$ os wrapped in the plaque core [97].

It is generally considered that $A \beta * 56$ has conspicuous toxicity to neurons, and is related to cognitive impairment in a variety of $\mathrm{AD}$ transgenic mice $[127,130,131]$. The expression of $A \beta * 56$ in olfactory epithelium significantly increases in the early onset of $\mathrm{Tg} 2576$ transgenic mice [132]. Brain-derived $A \beta * 56$ causes memory impairment by injecting to the brains of normal rats [109]. The mechanism by which $A \beta * 56$-induced neurotoxicity is that $A \beta * 56$ mainly binds to NMDAR on neuronal membranes to elevate NMDAR-dependent intracellular $\mathrm{Ca}^{2+}$ concentration by increasing $\mathrm{Ca}^{2+}$ inflow and activate $\mathrm{Ca}^{2+}$-dependent calmodulin kinase $\mathrm{II} \alpha(\mathrm{CaMKII} \alpha)$. The activated CaMKII $\alpha$ may promote the hyperphosphorylation of tau at Ser202 and Ser 416 and trigger AD-related pathological changes $[110,111]$. Moreover, a recent study suggested that $A \beta^{*} 56$ also damaged ubiquitin-dependent and ubiquitin-independent proteasome functions and promoted cell death [112].

\subsection{Spherical Oligomers}

\subsubsection{ASPD}

ASPD are spherical oligomers assembled by A $\beta 40$ or A $\beta 42$ with diameter being $11.9 \pm 1.7 \mathrm{~nm}$ in transmission electron microscopic (TEM) images [133,134]. ASPD can be assembled into spherical oligomers with a molecular weight of $330 \mathrm{kDa}$ in units of trimers after $5 \mathrm{~h}$ of aggregation in vitro. Even if the reaction time exceeds $24 \mathrm{~h}$, the main fragment in the solution remains to be oligomers without fiber formation, indicating that ASPD aggregation is off-fibril pathway [20]. ASPD do not bind to $\mathrm{A} 11$ and $\mathrm{OC}$, indicating that they have a unique conformation different from $\mathrm{A} \beta$ dimers, $A \beta^{* 56}$ and other A11-reactive entities [135]. Previous study demonstrated that ASPD had higher neurotoxicity by exerting synaptic damage and inhibiting LTP, but ASPD did not exhibit toxicity to glial cells when they were applied to rat hippocampal slices [113]. After binding to the fourth extracellular loop (Ex4) of $\mathrm{Na}^{+} / \mathrm{K}^{+}$-ATPase $\alpha 3$ subunit (NAK $\alpha 3$ ) in neurons, brain-derived ASPD cause the impairment of NAK $\alpha 3$-specific activity and the activation of N-type voltage-gated calcium channels, both of which can 
increase cytoplasmic $\mathrm{Ca}^{2+}$ levels and induce mitochondrial calcium dyshomeostasis, leading to mature neurons death and cognitive impairment eventually $[20,114]$. Further research on the distribution and spread of ASPD among different neurons identified that ASPD mainly accumulated in the trans-Golgi network of excitatory neurons and after secreted by these neurons, ASPD invaded and caused the death of surrounding NAK $\alpha 3$-positive neurons [136]. In general, ASPD are A $\beta$ os with unique conformation and robust neurotoxicity.

\subsubsection{ADDLs}

$A \beta$-derived diffusible aggregates (ADDLs) are also spherical oligomers that can be detected in AD human brains [137]. The content of ADDLs in brain of Tg2576 mice increases by $5-100$ times before a change in spatial memory [138]. ADDLs are small sphere with a diameter of 5-6 nm and can be specifically recognized by the ADDLs-specific antibodies termed as NUx [139]. ADDLs bind to mature neurons, generate neurotoxicity, and induce abnormal autophagy of neurons [115]. In addition, ADDLs can reduce the level of insulin receptor in neurons and disrupt normal insulin signaling [116,117]. They may also bind to EPhB2, trigger the receptor degradation and the phosphorylation of NMDAR, and impair synaptic plasticity [118]. Moreover, ADDLs can lead to abnormal localization of tau to dendrites of primary neurons by activating tyrosine kinase Fyn $[119,120]$. The latest study showed that after binding to the dendrites and spines of cortical pyramidal neurons, ADDLs induced the rapid depletion of kalirin-7 and caused spine dysgenesis [140].

\section{Discussion}

It is widely accepted that $\mathrm{A} \beta$ os rather than monomers and fibrils play a critical role in $\mathrm{AD}$ progression. A $\beta$ os can trigger a series of toxic reactions in neurons, such as receptor disability, mitochondrial damage, $\mathrm{Ca}^{2+}$ homeostasis dysregulation and abnormal tau phosphorylation, but the abnormalities of these activities also aggravate accumulation and aggregation of $\mathrm{A} \beta$, forming a vicious cycle. In addition, A $\beta$ os are unstable and highly heterogeneous, having various sizes, structures and toxicities both in vivo and in vitro, and play different roles at different phages of AD pathogenesis, resulting in differential consequences on neuronal synaptotoxicity and survival.

Because of the important roles of $A \beta$ in $A D$ pathogenicity, many drugs targeting $A \beta$ have been developed to reduce the production of $A \beta$ or promote the removal of $A \beta$ aggregates and plaque deposits in the brain. Unfortunately, these drugs have failed in the clinical trials due to severe side effects or inability to improve cognitive impairment of AD patients. There may be four reasons for the failure of $A \beta$-targeted treatment strategies. Firstly, a large number of clinical trials have shown that $\beta$-secretase and $\gamma$-secretase inhibitors not only fail to effectively improve cognitive impairment of AD patients, but also lead to cognitive deterioration and serious side effects [141,142], which may be attributable to the sharp decrease in the levels of $A \beta$ monomer and secretases, resulting in the inhibition of normal physiological functions of $A \beta$ monomers and secretases. Secondly, many antibodies and vaccines targeting $A \beta$ monomers, oligomers or fibers, such as bapinezumab [143], solanezumab [144] and AN-1792 [145] may not effectively bind to pathogenic oligomer, and usually induce serious side effects. Thirdly, the stage is too late for the tested drugs to interfere with AD development. A $\beta$ aggregates exist in the brain as early as 10-20 years before the occurrence of clinical symptoms, but the current clinical trials of drugs intervene on patients with mild-to-moderate symptomatic. At this stage, a large number of neuronal deaths and irreversible cognitive impairments have occurred in the brains of patients. Finally, AD is a chronic neurodegenerative disease with complex pathological mechanisms, and the exact pathogenesis is currently unclear. In addition to the amyloid cascade hypothesis, researchers also found that tau protein, neuroinflammation and other factors also play important roles in the development of $\mathrm{AD}$. According to the current theoretical basis, drugs just against $\mathrm{A} \beta$ may not effectively reverse the pathological processes of $\mathrm{AD}$. In the future, the combination of multiple drugs targeting different pathogenic factors should be considered, which may bring exciting results to AD treatment. 
Although significant progress in understanding the biological characteristics of $A \beta$ and the role in the pathogenesis of $A D$ have been made, we have not yet clarified the aggregation kinetics of $A \beta$, and systematically understood the relationship between different $\mathrm{A} \beta$ os and $\mathrm{AD}$ development due to the heterogeneity and instability of Aßos. Some methods used in the current study to extract and detect $A \beta$ os, such as denaturants and SDS-PAGE, may affect the structures and properties of Aßos. In order to obtain high-purity and biologically active $A \beta o$, more gentle methods to separate and purify different $A \beta$ os should be explored. In recent years, the acquisition of $A \beta$ os has been transformed from incubation with synthesized $A \beta$ to extraction from the brains of $A D$ transgenic mice, making it possible to explore the relationship between pathophysiologic $\mathrm{A} \beta$ os and $\mathrm{AD}$ pathological changes. However, the biological characteristics of $A \beta$ os in the brain of AD patients are scarcely studied. Moreover, $A \beta 0$ os exist in the brain long before the occurrence of clinical symptoms, and it is necessary to monitor $A \beta O$ os in the brain of patients at the preclinical stage to clarify the chronological sequence of different $A \beta$ os in AD human, and their detailed toxic mechanisms. More importantly, the structural characteristics of $\mathrm{A} \beta$ os that play a vital role in $\mathrm{AD}$ pathology should be analyzed, and then the therapies against these toxic $\mathrm{A} \beta$ os could be designed and developed.

Author Contributions: Conceptualization, Y.-r.H. and R.-t.L.; Literature Collection, Writing-Original Draft Preparation, Y.-r.H.; Writing-Review \& Editing, Y.-r.H. and R.-t.L.; Supervision, R.-t.L.; Funding Acquisition, R.-t.L. All authors have read and agreed to the published version of the manuscript.

Funding: This work was funded by the grants from the National Natural Science Foundation of China, grant number: 81971610 and 81971073.

Conflicts of Interest: The authors declare no conflict of interest.

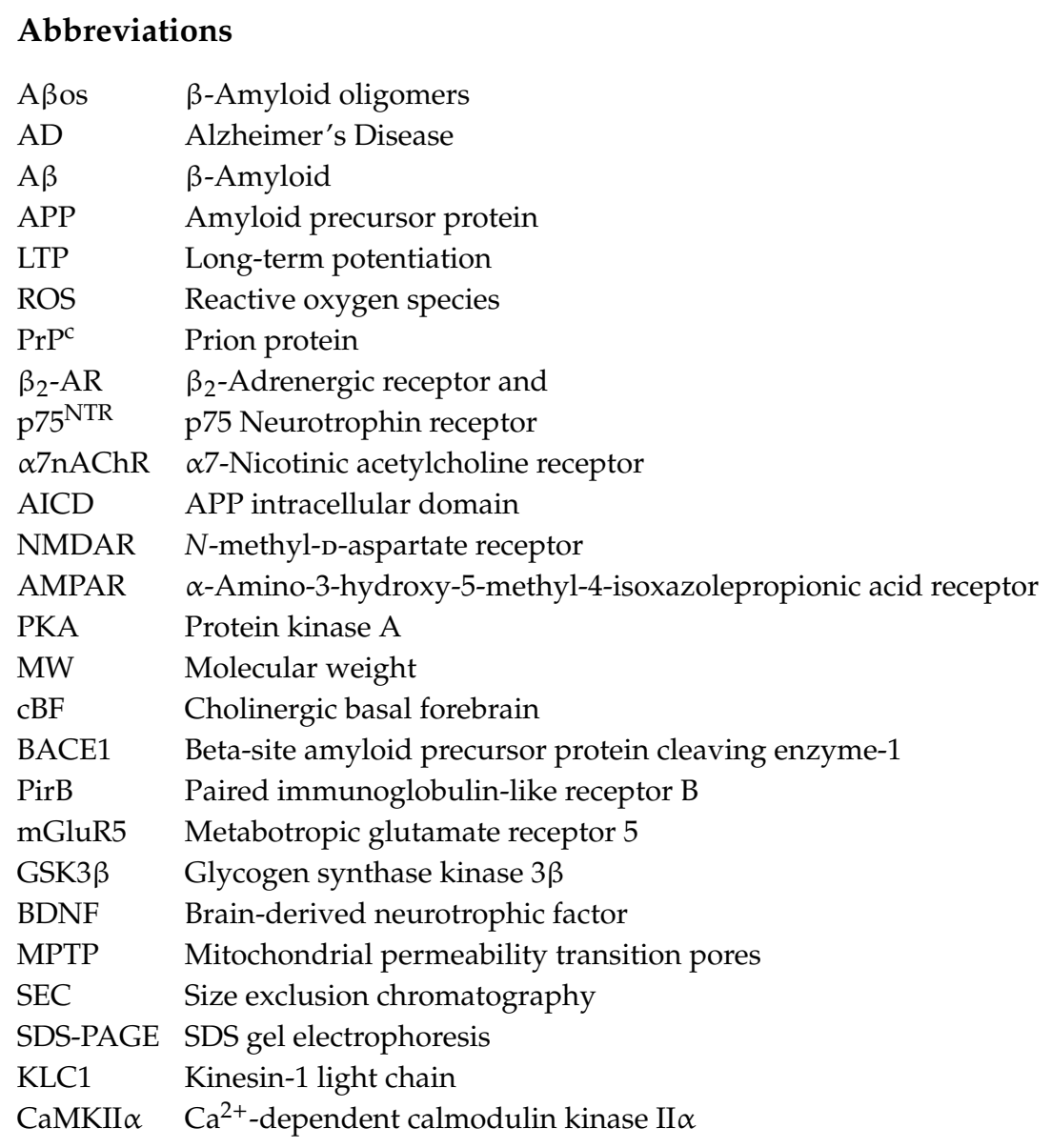


ASPD Amylospheroids

TEM Transmission electron microscopic

NAK $\alpha 3 \quad \mathrm{Na}^{+} / \mathrm{K}^{+}$-ATPase $\alpha 3$ subunit

ADDLs $\quad \mathrm{A} \beta$-derived diffusible aggregates

\section{References}

1. Alzheimer's Association. 2019 Alzheimer's disease facts and figures. Alzheimers Dement. 2019, 15, 321-387. [CrossRef]

2. Jack, C.R., Jr.; Bennett, D.A.; Blennow, K.; Carrillo, M.C.; Dunn, B.; Haeberlein, S.B.; Holtzman, D.M.; Jagust, W.; Jessen, F.; Karlawish, J.; et al. NIA-AA Research Framework: Toward a biological definition of Alzheimer's disease. Alzheimers Dement. 2018, 14, 535-562. [CrossRef] [PubMed]

3. Kumar, D.K.; Choi, S.H.; Washicosky, K.J.; Eimer, W.A.; Tucker, S.; Ghofrani, J.; Lefkowitz, A.; McColl, G.; Goldstein, L.E.; Tanzi, R.E.; et al. Amyloid-beta peptide protects against microbial infection in mouse and worm models of Alzheimer's disease. Sci. Transl. Med. 2016, 8, 340ra372. [CrossRef] [PubMed]

4. Selkoe, D.J.; Hardy, J. The amyloid hypothesis of Alzheimer's disease at 25 years. EMBO Mol. Med. 2016, 8, 595-608. [CrossRef]

5. Koike, H.; Seki, H.; Kouchi, Z.; Ito, M.; Kinouchi, T.; Tomioka, S.; Sorimachi, H.; Saido, T.C.; Maruyama, K.; Suzuki, K.; et al. Thimet oligopeptidase cleaves the full-length Alzheimer amyloid precursor protein at a beta-secretase cleavage site in COS cells. J. Biochem. 1999, 126, 235-242. [CrossRef]

6. Levitan, D.; Lee, J.; Song, L.; Manning, R.; Wong, G.; Parker, E.; Zhang, L. PS1 N- and C-terminal fragments form a complex that functions in APP processing and Notch signaling. Proc. Natl. Acad. Sci. USA 2001, 98, 12186-12190. [CrossRef]

7. Wei, W.; Nguyen, L.N.; Kessels, H.W.; Hagiwara, H.; Sisodia, S.; Malinow, R. Amyloid beta from axons and dendrites reduces local spine number and plasticity. Nat. Neurosci. 2010, 13, 190-196. [CrossRef] [PubMed]

8. Kamenetz, F.; Tomita, T.; Hsieh, H.; Seabrook, G.; Borchelt, D.; Iwatsubo, T.; Sisodia, S.; Malinow, R. APP processing and synaptic function. Neuron 2003, 37, 925-937. [CrossRef]

9. Whitson, J.S.; Selkoe, D.J.; Cotman, C.W. Amyloid beta protein enhances the survival of hippocampal neurons in vitro. Science 1989, 243, 1488-1490. [CrossRef]

10. Koo, E.H.; Park, L.; Selkoe, D.J. Amyloid beta-protein as a substrate interacts with extracellular matrix to promote neurite outgrowth. Proc. Natl. Acad. Sci. USA 1993, 90, 4748-4752. [CrossRef]

11. Eimer, W.A.; Kumar, D.K.V.; Shanmugam, N.K.N.; Rodriguez, A.S.; Mitchell, T.; Washicosky, K.J.; Gyorgy, B.; Breakefield, X.O.; Tanzi, R.E.; Moir, R.D. Alzheimer's Disease-Associated beta-Amyloid Is Rapidly Seeded by Herpesviridae to Protect against Brain Infection. Neuron 2018, 99, 56-63.e3. [CrossRef] [PubMed]

12. Bourgade, K.; Le Page, A.; Bocti, C.; Witkowski, J.M.; Dupuis, G.; Frost, E.H.; Fulop, T., Jr. Protective Effect of Amyloid-beta Peptides Against Herpes Simplex Virus-1 Infection in a Neuronal Cell Culture Model. J. Alzheimers Dis. 2016, 50, 1227-1241. [CrossRef]

13. Hubin, E.; Deroo, S.; Schierle, G.K.; Kaminski, C.; Serpell, L.; Subramaniam, V.; van Nuland, N.; Broersen, K.; Raussens, V.; Sarroukh, R. Two distinct beta-sheet structures in Italian-mutant amyloid-beta fibrils: A potential link to different clinical phenotypes. Cell. Mol. Life Sci. 2015, 72, 4899-4913. [CrossRef]

14. Luo, J.; Warmlander, S.K.; Graslund, A.; Abrahams, J.P. Reciprocal Molecular Interactions between the Abeta Peptide Linked to Alzheimer's Disease and Insulin Linked to Diabetes Mellitus Type II. ACS Chem. Neurosci. 2016, 7, 269-274. [CrossRef] [PubMed]

15. Tornquist, M.; Michaels, T.C.T.; Sanagavarapu, K.; Yang, X.; Meisl, G.; Cohen, S.I.A.; Knowles, T.P.J.; Linse, S. Secondary nucleation in amyloid formation. Chem. Commun. 2018, 54, 8667-8684. [CrossRef]

16. Michaels, T.C.T.; Saric, A.; Curk, S.; Bernfur, K.; Arosio, P.; Meisl, G.; Dear, A.J.; Cohen, S.I.A.; Dobson, C.M.; Vendruscolo, M.; et al. Dynamics of oligomer populations formed during the aggregation of Alzheimer's Abeta42 peptide. Nat. Chem. 2020, 12, 445-451. [CrossRef]

17. Szczepankiewicz, O.; Linse, B.; Meisl, G.; Thulin, E.; Frohm, B.; Sala Frigerio, C.; Colvin, M.T.; Jacavone, A.C.; Griffin, R.G.; Knowles, T.; et al. N-Terminal Extensions Retard Abeta42 Fibril Formation but Allow Cross-Seeding and Coaggregation with Abeta42. J. Am. Chem. Soc. 2015, 137, 14673-14685. [CrossRef] [PubMed] 
18. Knowles, T.P.; Waudby, C.A.; Devlin, G.L.; Cohen, S.I.; Aguzzi, A.; Vendruscolo, M.; Terentjev, E.M.; Welland, M.E.; Dobson, C.M. An analytical solution to the kinetics of breakable filament assembly. Science 2009, 326, 1533-1537. [CrossRef]

19. Fandrich, M. Oligomeric intermediates in amyloid formation: Structure determination and mechanisms of toxicity. J. Mol. Biol. 2012, 421, 427-440. [CrossRef]

20. Matsumura, S.; Shinoda, K.; Yamada, M.; Yokojima, S.; Inoue, M.; Ohnishi, T.; Shimada, T.; Kikuchi, K.; Masui, D.; Hashimoto, S.; et al. Two distinct amyloid beta-protein (Abeta) assembly pathways leading to oligomers and fibrils identified by combined fluorescence correlation spectroscopy, morphology, and toxicity analyses. J. Biol. Chem. 2011, 286, 11555-11562. [CrossRef]

21. Gellermann, G.P.; Byrnes, H.; Striebinger, A.; Ullrich, K.; Mueller, R.; Hillen, H.; Barghorn, S. Abeta-globulomers are formed independently of the fibril pathway. Neurobiol. Dis. 2008, 30, 212-220. [CrossRef] [PubMed]

22. Tabaton, M.; Nunzi, M.G.; Xue, R.; Usiak, M.; Autilio-Gambetti, L.; Gambetti, P. Soluble amyloid beta-protein is a marker of Alzheimer amyloid in brain but not in cerebrospinal fluid. Biochem. Biophys. Res. Commun. 1994, 200, 1598-1603. [CrossRef] [PubMed]

23. Frackowiak, J.; Zoltowska, A.; Wisniewski, H.M. Non-fibrillar beta-amyloid protein is associated with smooth muscle cells of vessel walls in Alzheimer disease. J. Neuropathol. Exp. Neurol. 1994, 53, 637-645. [CrossRef] [PubMed]

24. Hardy, J.A.; Higgins, G.A. Alzheimer's disease: The amyloid cascade hypothesis. Science 1992, 256, $184-185$. [CrossRef]

25. Hardy, J.; Selkoe, D.J. The amyloid hypothesis of Alzheimer's disease: Progress and problems on the road to therapeutics. Science 2002, 297, 353-356. [CrossRef]

26. Mroczko, B.; Groblewska, M.; Litman-Zawadzka, A.; Kornhuber, J.; Lewczuk, P. Cellular Receptors of Amyloid beta Oligomers (AbetaOs) in Alzheimer's Disease. Int J. Mol. Sci. 2018, 19, 1884. [CrossRef]

27. Vincent, B.; Sunyach, C.; Orzechowski, H.D.; St George-Hyslop, P.; Checler, F. p53-Dependent transcriptional control of cellular prion by presenilins. J. Neurosci. 2009, 29, 6752-6760. [CrossRef]

28. Younan, N.D.; Chen, K.F.; Rose, R.S.; Crowther, D.C.; Viles, J.H. Prion protein stabilizes amyloid-beta (Abeta) oligomers and enhances Abeta neurotoxicity in a Drosophila model of Alzheimer's disease. J. Biol. Chem. 2018, 293, 13090-13099. [CrossRef]

29. Pagano, K.; Galante, D.; D'Arrigo, C.; Corsaro, A.; Nizzari, M.; Florio, T.; Molinari, H.; Tomaselli, S.; Ragona, L. Effects of Prion Protein on Abeta42 and Pyroglutamate-Modified AbetapEpsilon3-42 Oligomerization and Toxicity. Mol. Neurobiol. 2019, 56, 1957-1971. [CrossRef]

30. Haas, L.T.; Salazar, S.V.; Kostylev, M.A.; Um, J.W.; Kaufman, A.C.; Strittmatter, S.M. Metabotropic glutamate receptor 5 couples cellular prion protein to intracellular signalling in Alzheimer's disease. Brain 2016, 139, 526-546. [CrossRef]

31. Um, J.W.; Nygaard, H.B.; Heiss, J.K.; Kostylev, M.A.; Stagi, M.; Vortmeyer, A.; Wisniewski, T.; Gunther, E.C.; Strittmatter, S.M. Alzheimer amyloid-beta oligomer bound to postsynaptic prion protein activates Fyn to impair neurons. Nat. Neurosci. 2012, 15, 1227-1235. [CrossRef] [PubMed]

32. Corbett, G.T.; Wang, Z.; Hong, W.; Colom-Cadena, M.; Rose, J.; Liao, M.; Asfaw, A.; Hall, T.C.; Ding, L.; DeSousa, A.; et al. PrP is a central player in toxicity mediated by soluble aggregates of neurodegeneration-causing proteins. Acta Neuropathol. 2019. [CrossRef] [PubMed]

33. Zhang, D.; Qi, Y.; Klyubin, I.; Ondrejcak, T.; Sarell, C.J.; Cuello, A.C.; Collinge, J.; Rowan, M.J. Targeting glutamatergic and cellular prion protein mechanisms of amyloid beta-mediated persistent synaptic plasticity disruption: Longitudinal studies. Neuropharmacology 2017, 121, 231-246. [CrossRef]

34. Li, F.; Tsien, J.Z. Memory and the NMDA receptors. N. Engl. J. Med. 2009, 361, 302-303. [CrossRef]

35. Muller, M.K.; Jacobi, E.; Sakimura, K.; Malinow, R.; von Engelhardt, J. NMDA receptors mediate synaptic depression, but not spine loss in the dentate gyrus of adult amyloid Beta (Abeta) overexpressing mice. Acta Neuropathol. Commun. 2018, 6, 110. [CrossRef]

36. Liang, J.; Kulasiri, D.; Samarasinghe, S. Computational investigation of Amyloid-beta-induced location- and subunit-specific disturbances of NMDAR at hippocampal dendritic spine in Alzheimer's disease. PLoS ONE 2017, 12, e0182743. [CrossRef]

37. Diering, G.H.; Huganir, R.L. The AMPA Receptor Code of Synaptic Plasticity. Neuron 2018, 100, 314-329. [CrossRef] 
38. Zhang, Y.; Guo, O.; Huo, Y.; Wang, G.; Man, H.Y. Amyloid-beta Induces AMPA Receptor Ubiquitination and Degradation in Primary Neurons and Human Brains of Alzheimer's Disease. J. Alzheimers Dis. 2018, 62, 1789-1801. [CrossRef]

39. Miller, E.C.; Teravskis, P.J.; Dummer, B.W.; Zhao, X.; Huganir, R.L.; Liao, D. Tau phosphorylation and tau mislocalization mediate soluble Abeta oligomer-induced AMPA glutamate receptor signaling deficits. Eur. J. Neurosci. 2014, 39, 1214-1224. [CrossRef]

40. Wang, D.; Fu, Q.; Zhou, Y.; Xu, B.; Shi, Q.; Igwe, B.; Matt, L.; Hell, J.W.; Wisely, E.V.; Oddo, S.; et al. Beta2 adrenergic receptor, protein kinase A (PKA) and c-Jun N-terminal kinase (JNK) signaling pathways mediate tau pathology in Alzheimer disease models. J. Biol. Chem. 2013, 288, 10298-10307. [CrossRef]

41. Wang, D.; Govindaiah, G.; Liu, R.; De Arcangelis, V.; Cox, C.L.; Xiang, Y.K. Binding of amyloid beta peptide to beta2 adrenergic receptor induces PKA-dependent AMPA receptor hyperactivity. FASEB J. 2010, 24, 3511-3521. [CrossRef] [PubMed]

42. Yang, T.; Li, S.; Xu, H.; Walsh, D.M.; Selkoe, D.J. Large Soluble Oligomers of Amyloid beta-Protein from Alzheimer Brain Are Far Less Neuroactive Than the Smaller Oligomers to Which They Dissociate. J. Neurosci. 2017, 37, 152-163. [CrossRef] [PubMed]

43. Wang, Y.R.; Wang, J.; Liu, Y.H.; Hu, G.L.; Gao, C.Y.; Wang, Y.J.; Zhou, X.F.; Zeng, F. Cysteine-Rich Repeat Domains 2 and 4 are Amyloid-beta Binding Domains of Neurotrophin Receptor p75NTR and Potential Targets to Block Amyloid-beta Neurotoxicity. J. Alzheimers Dis. 2018, 63, 139-147. [CrossRef] [PubMed]

44. Shen, L.L.; Li, W.W.; Xu, Y.L.; Gao, S.H.; Xu, M.Y.; Bu, X.L.; Liu, Y.H.; Wang, J.; Zhu, J.; Zeng, F.; et al. Neurotrophin receptor p75 mediates amyloid beta-induced tau pathology. Neurobiol. Dis. 2019, 132, 104567. [CrossRef]

45. Manucat-Tan, N.B.; Shen, L.L.; Bobrovskaya, L.; Al-Hawwas, M.; Zhou, F.H.; Wang, Y.J.; Zhou, X.F. Knockout of p75 neurotrophin receptor attenuates the hyperphosphorylation of Tau in pR5 mouse model. Aging Albany Ny 2019, 11, 6762-6791.

46. Qian, L.; Milne, M.R.; Shepheard, S.; Rogers, M.L.; Medeiros, R.; Coulson, E.J. Removal of p75 Neurotrophin Receptor Expression from Cholinergic Basal Forebrain Neurons Reduces Amyloid-beta Plaque Deposition and Cognitive Impairment in Aged APP/PS1 Mice. Mol. Neurobiol. 2019, 56, 4639-4652. [CrossRef] [PubMed]

47. Saadipour, K.; Manucat-Tan, N.B.; Lim, Y.; Keating, D.J.; Smith, K.S.; Zhong, J.H.; Liao, H.; Bobrovskaya, L.; Wang, Y.J.; Chao, M.V.; et al. p75 neurotrophin receptor interacts with and promotes BACE1 localization in endosomes aggravating amyloidogenesis. J. Neurochem. 2018, 144, 302-317. [CrossRef] [PubMed]

48. Yao, X.Q.; Jiao, S.S.; Saadipour, K.; Zeng, F.; Wang, Q.H.; Zhu, C.; Shen, L.L.; Zeng, G.H.; Liang, C.R.; Wang, J.; et al. p75NTR ectodomain is a physiological neuroprotective molecule against amyloid-beta toxicity in the brain of Alzheimer's disease. Mol. Psychiatry 2015, 20, 1301-1310. [CrossRef]

49. Wang, Y.; Tang, H.; Yang, C.; Zhao, H.; Jian, C. Involvement of p75NTR in the effects of Abeta on L-type $\mathrm{Ca}(2+)$ channel in cultured neuronal networks. Life Sci. 2020, 243, 117293. [CrossRef]

50. Cecon, E.; Dam, J.; Luka, M.; Gautier, C.; Chollet, A.M.; Delagrange, P.; Danober, L.; Jockers, R. Quantitative assessment of oligomeric amyloid beta peptide binding to alpha7 nicotinic receptor. Br. J. Pharm. 2019, 176, 3475-3488. [CrossRef]

51. Bencherif, M.; Lippiello, P.M. Alpha7 neuronal nicotinic receptors: The missing link to understanding Alzheimer's etiopathology? Med. Hypotheses 2010, 74, 281-285. [CrossRef] [PubMed]

52. Barykin, E.P.; Garifulina, A.I.; Kruykova, E.V.; Spirova, E.N.; Anashkina, A.A.; Adzhubei, A.A.; Shelukhina, I.V.; Kasheverov, I.E.; Mitkevich, V.A.; Kozin, S.A.; et al. Isomerization of Asp7 in Beta-Amyloid Enhances Inhibition of the alpha7 Nicotinic Receptor and Promotes Neurotoxicity. Cells 2019, 8, 771. [CrossRef]

53. Takata, K.; Amamiya, T.; Mizoguchi, H.; Kawanishi, S.; Kuroda, E.; Kitamura, R.; Ito, A.; Saito, Y.; Tawa, M.; Nagasawa, T.; et al. Alpha7 nicotinic acetylcholine receptor-specific agonist DMXBA (GTS-21) attenuates Abeta accumulation through suppression of neuronal gamma-secretase activity and promotion of microglial amyloid-beta phagocytosis and ameliorates cognitive impairment in a mouse model of Alzheimer's disease. Neurobiol. Aging 2018, 62, 197-209. [PubMed]

54. Chang, K.W.; Zong, H.F.; Rizvi, M.Y.; Ma, K.G.; Zhai, W.; Wang, M.; Yang, W.N.; Ji, S.F.; Qian, Y.H. Modulation of the MAPKs pathways affects Abeta-induced cognitive deficits in Alzheimer's disease via activation of alpha7nAChR. Neurobiol. Learn. Mem 2020, 168, 107154. [CrossRef] [PubMed] 
55. Chang, K.W.; Zong, H.F.; Ma, K.G.; Zhai, W.Y.; Yang, W.N.; Hu, X.D.; Xu, J.H.; Chen, X.L.; Ji, S.F.; Qian, Y.H. Activation of alpha7 nicotinic acetylcholine receptor alleviates Abeta1-42-induced neurotoxicity via downregulation of p38 and JNK MAPK signaling pathways. Neurochem. Int. 2018, 120, 238-250. [CrossRef] [PubMed]

56. Kim, T.; Vidal, G.S.; Djurisic, M.; William, C.M.; Birnbaum, M.E.; Garcia, K.C.; Hyman, B.T.; Shatz, C.J. Human LilrB2 is a beta-amyloid receptor and its murine homolog PirB regulates synaptic plasticity in an Alzheimer's model. Science 2013, 341, 1399-1404. [CrossRef]

57. Cao, Q.; Shin, W.S.; Chan, H.; Vuong, C.K.; Dubois, B.; Li, B.; Murray, K.A.; Sawaya, M.R.; Feigon, J.; Black, D.L.; et al. Inhibiting amyloid-beta cytotoxicity through its interaction with the cell surface receptor LilrB2 by structure-based design. Nat. Chem. 2018, 10, 1213-1221. [CrossRef]

58. Miyamoto, T.; Kim, D.; Knox, J.A.; Johnson, E.; Mucke, L. Increasing the Receptor Tyrosine Kinase EphB2 Prevents Amyloid-beta-induced Depletion of Cell Surface Glutamate Receptors by a Mechanism That Requires the PDZ-binding Motif of EphB2 and Neuronal Activity. J. Biol. Chem. 2016, 291, 1719-1734. [CrossRef]

59. Hu, R.; Wei, P.; Jin, L.; Zheng, T.; Chen, W.Y.; Liu, X.Y.; Shi, X.D.; Hao, J.R.; Sun, N.; Gao, C. Overexpression of EphB2 in hippocampus rescues impaired NMDA receptors trafficking and cognitive dysfunction in Alzheimer model. Cell Death Dis. 2017, 8, e2717. [CrossRef]

60. Lee, M.; Lee, H.J.; Park, I.S.; Park, J.A.; Kwon, Y.J.; Ryu, Y.H.; Kim, C.H.; Kang, J.H.; Hyun, I.Y.; Lee, K.C.; et al. Abeta pathology downregulates brain mGluR5 density in a mouse model of Alzheimer. Neuropharmacology 2018, 133, 512-517. [CrossRef]

61. Brody, A.H.; Strittmatter, S.M. Synaptotoxic Signaling by Amyloid Beta Oligomers in Alzheimer's Disease Through Prion Protein and mGluR5. Adv. Pharm. 2018, 82, 293-323.

62. Kayed, R.; Lasagna-Reeves, C.A. Molecular mechanisms of amyloid oligomers toxicity. J. Alzheimers Dis. 2013, 33, S67-S78. [CrossRef] [PubMed]

63. Bode, D.C.; Baker, M.D.; Viles, J.H. Ion Channel Formation by Amyloid-beta42 Oligomers but Not Amyloid-beta40 in Cellular Membranes. J. Biol. Chem. 2017, 292, 1404-1413. [CrossRef] [PubMed]

64. Bode, D.C.; Freeley, M.; Nield, J.; Palma, M.; Viles, J.H. Amyloid- $\beta$ oligomers have a profound detergent-like effect on lipid membrane bilayers, imaged by atomic force and electron microscopy. J. Biol. Chem. 2019, 294, 7566-7572. [CrossRef]

65. Yasumoto, T.; Takamura, Y.; Tsuji, M.; Watanabe-Nakayama, T.; Imamura, K.; Inoue, H.; Nakamura, S.; Inoue, T.; Kimura, A.; Yano, S.; et al. High molecular weight amyloid beta1-42 oligomers induce neurotoxicity via plasma membrane damage. FASEB J. 2019, 33, 9220-9234. [CrossRef]

66. Dong, X.; Sun, Y.; Wei, G.; Nussinov, R.; Ma, B. Binding of protofibrillar Abeta trimers to lipid bilayer surface enhances Abeta structural stability and causes membrane thinning. Phys. Chem. Chem. Phys. 2017, 19, 27556-27569. [CrossRef]

67. Jang, H.; Connelly, L.; Arce, F.T.; Ramachandran, S.; Kagan, B.L.; Lal, R.; Nussinov, R. Mechanisms for the Insertion of Toxic, Fibril-like beta-Amyloid Oligomers into the Membrane. J. Chem. Theory Comput. 2013, 9, 822-833. [CrossRef]

68. Serra-Batiste, M.; Ninot-Pedrosa, M.; Bayoumi, M.; Gairi, M.; Maglia, G.; Carulla, N. A beta 42 assembles into specific beta-barrel pore-forming oligomers in membrane-mimicking environments. Proc. Natl. Acad. Sci. USA 2016, 113, 10866-10871. [CrossRef]

69. Fernandez-Perez, E.J.; Sepulveda, F.J.; Peters, C.; Bascunan, D.; Riffo-Lepe, N.O.; Gonzalez-Sanmiguel, J.; Sanchez, S.A.; Peoples, R.W.; Vicente, B.; Aguayo, L.G. Effect of Cholesterol on Membrane Fluidity and Association of Abeta Oligomers and Subsequent Neuronal Damage: A Double-Edged Sword. Front. Aging Neurosci. 2018, 10, 226. [CrossRef]

70. Vahed, M.; Neya, S.; Matsuzaki, K.; Hoshino, T. Analysis of Physicochemical Interaction of Abeta40 with a GM1 Ganglioside-Containing Lipid Membrane. J. Phys. Chem. B 2018, 122, 3771-3781. [CrossRef]

71. Hong, S.; Ostaszewski, B.L.; Yang, T.; O’Malley, T.T.; Jin, M.; Yanagisawa, K.; Li, S.; Bartels, T.; Selkoe, D.J. Soluble Abeta oligomers are rapidly sequestered from brain ISF in vivo and bind GM1 ganglioside on cellular membranes. Neuron 2014, 82, 308-319. [CrossRef] [PubMed]

72. Lockhart, C.; Klimov, D.K. Cholesterol Changes the Mechanisms of Abeta Peptide Binding to the DMPC Bilayer. J. Chem. Inf. Model. 2017, 57, 2554-2565. [CrossRef] [PubMed] 
73. Fernandez-Perez, E.J.; Sepulveda, F.J.; Peoples, R.; Aguayo, L.G. Role of membrane GM1 on early neuronal membrane actions of Abeta during onset of Alzheimer's disease. Biochim. Biophys. Acta Mol. Basis Dis. 2017, 1863, 3105-3116. [CrossRef] [PubMed]

74. Dai, Y.; Zhang, M.; Shi, X.; Wang, K.; Gao, G.; Shen, L.; Sun, T. Kinetic study of Abeta(1-42) amyloidosis in the presence of ganglioside-containing vesicles. Colloids Surf. B Biointerfaces 2020, 185, 110615. [CrossRef] [PubMed]

75. Ferreira, S.T.; Klein, W.L. The Abeta oligomer hypothesis for synapse failure and memory loss in Alzheimer's disease. Neurobiol. Learn. Mem. 2011, 96, 529-543. [CrossRef]

76. Sun, J.L.; Stokoe, S.A.; Roberts, J.P.; Sathler, M.F.; Nip, K.A.; Shou, J.; Ko, K.; Tsunoda, S.; Kim, S. Co-activation of selective nicotinic acetylcholine receptors is required to reverse beta amyloid-induced $\mathrm{Ca}(2+)$ hyperexcitation. Neurobiol. Aging 2019, 84, 166-177. [CrossRef]

77. Gan, K.J.; Silverman, M.A. Dendritic and axonal mechanisms of $\mathrm{Ca}^{2+}$ elevation impair BDNF transport in Abeta oligomer-treated hippocampal neurons. Mol. Biol. Cell 2015, 26, 1058-1071. [CrossRef]

78. Shoshan-Barmatz, V.; De, S.; Meir, A. The Mitochondrial Voltage-Dependent Anion Channel 1, Ca(2+) Transport, Apoptosis, and Their Regulation. Front. Oncol 2017, 7, 60. [CrossRef]

79. Swerdlow, R.H. Mitochondria and Mitochondrial Cascades in Alzheimer's Disease. J. Alzheimers Dis. 2018, 62, 1403-1416. [CrossRef]

80. Du, H.; Guo, L.; Fang, F.; Chen, D.; Sosunov, A.A.; McKhann, G.M.; Yan, Y.; Wang, C.; Zhang, H.; Molkentin, J.D.; et al. Cyclophilin D deficiency attenuates mitochondrial and neuronal perturbation and ameliorates learning and memory in Alzheimer's disease. Nat. Med. 2008, 14, 1097-1105. [CrossRef]

81. Luongo, T.S.; Lambert, J.P.; Yuan, A.; Zhang, X.; Gross, P.; Song, J.; Shanmughapriya, S.; Gao, E.; Jain, M.; Houser, S.R.; et al. The Mitochondrial Calcium Uniporter Matches Energetic Supply with Cardiac Workload during Stress and Modulates Permeability Transition. Cell Rep. 2015, 12, 23-34. [CrossRef] [PubMed]

82. Wang, H.; Zhang, T.; Ge, X.; Chen, J.; Zhao, Y.; Fu, J. Parkin overexpression attenuates Abeta-induced mitochondrial dysfunction in HEK293 cells by restoring impaired mitophagy. Life Sci. 2020, 244, 117322. [CrossRef] [PubMed]

83. Youle, R.J.; Narendra, D.P. Mechanisms of mitophagy. Nat. Rev. Mol. Cell Biol. 2011, 12, 9-14. [CrossRef] [PubMed]

84. Zhao, N.; Yan, Q.W.; Xia, J.; Zhang, X.L.; Li, B.X.; Yin, L.Y.; Xu, B. Treadmill Exercise Attenuates Abeta-Induced Mitochondrial Dysfunction and Enhances Mitophagy Activity in APP/PS1 Transgenic Mice. Neurochem. Res. 2020, 45, 1202-1214. [CrossRef] [PubMed]

85. Fang, E.F.; Hou, Y.; Palikaras, K.; Adriaanse, B.A.; Kerr, J.S.; Yang, B.; Lautrup, S.; Hasan-Olive, M.M.; Caponio, D.; Dan, X.; et al. Mitophagy inhibits amyloid-beta and tau pathology and reverses cognitive deficits in models of Alzheimer's disease. Nat. Neurosci. 2019, 22, 401-412. [CrossRef] [PubMed]

86. Jadiya, P.; Kolmetzky, D.W.; Tomar, D.; Di Meco, A.; Lombardi, A.A.; Lambert, J.P.; Luongo, T.S.; Ludtmann, M.H.; Pratico, D.; Elrod, J.W. Impaired mitochondrial calcium efflux contributes to disease progression in models of Alzheimer's disease. Nat. Commun. 2019, 10, 3885. [CrossRef] [PubMed]

87. Hanseeuw, B.J.; Betensky, R.A.; Jacobs, H.I.L.; Schultz, A.P.; Sepulcre, J.; Becker, J.A.; Cosio, D.M.O.; Farrell, M.; Quiroz, Y.T.; Mormino, E.C.; et al. Association of Amyloid and Tau With Cognition in Preclinical Alzheimer Disease: A Longitudinal Study. JAMA Neurol 2019, 76, 915-924. [CrossRef]

88. Bateman, R.J.; Xiong, C.; Benzinger, T.L.; Fagan, A.M.; Goate, A.; Fox, N.C.; Marcus, D.S.; Cairns, N.J.; Xie, X.; Blazey, T.M.; et al. Clinical and biomarker changes in dominantly inherited Alzheimer's disease. N. Engl. J. Med. 2012, 367, 795-804. [CrossRef]

89. Vermunt, L.; Sikkes, S.A.M.; van den Hout, A.; Handels, R.; Bos, I.; van der Flier, W.M.; Kern, S.; Ousset, P.J.; Maruff, P.; Skoog, I.; et al. Duration of preclinical, prodromal, and dementia stages of Alzheimer's disease in relation to age, sex, and APOE genotype. Alzheimers Dement. 2019, 15, 888-898. [CrossRef]

90. Ossenkoppele, R.; Smith, R.; Ohlsson, T.; Strandberg, O.; Mattsson, N.; Insel, P.S.; Palmqvist, S.; Hansson, O. Associations between tau, A beta, and cortical thickness with cognition in Alzheimer disease. Neurology 2019, 92, E601-E612. [CrossRef]

91. Hurtado, D.E.; Molina-Porcel, L.; Iba, M.; Aboagye, A.K.; Paul, S.M.; Trojanowski, J.Q.; Lee, V.M. A\{beta\} accelerates the spatiotemporal progression of tau pathology and augments tau amyloidosis in an Alzheimer mouse model. Am. J. Pathol. 2010, 177, 1977-1988. [CrossRef] [PubMed] 
92. Forny-Germano, L.; Lyra e Silva, N.M.; Batista, A.F.; Brito-Moreira, J.; Gralle, M.; Boehnke, S.E.; Coe, B.C.; Lablans, A.; Marques, S.A.; Martinez, A.M.; et al. Alzheimer's disease-like pathology induced by amyloid-beta oligomers in nonhuman primates. J. Neurosci. 2014, 34, 13629-13643. [CrossRef] [PubMed]

93. He, Z.; Guo, J.L.; McBride, J.D.; Narasimhan, S.; Kim, H.; Changolkar, L.; Zhang, B.; Gathagan, R.J.; Yue, C.; Dengler, C.; et al. Amyloid-beta plaques enhance Alzheimer's brain tau-seeded pathologies by facilitating neuritic plaque tau aggregation. Nat. Med. 2018, 24, 29-38. [CrossRef] [PubMed]

94. Pontecorvo, M.J.; Devous, M.D.; Kennedy, I.; Navitsky, M.; Lu, M.; Galante, N.; Salloway, S.; Doraiswamy, P.M.; Southekal, S.; Arora, A.K.; et al. A multicentre longitudinal study of flortaucipir (18F) in normal ageing, mild cognitive impairment and Alzheimer's disease dementia. Brain 2019, 142, 1723-1735. [CrossRef]

95. Zhang, F.; Gannon, M.; Chen, Y.; Yan, S.; Zhang, S.; Feng, W.; Tao, J.; Sha, B.; Liu, Z.; Saito, T.; et al. beta-amyloid redirects norepinephrine signaling to activate the pathogenic GSK3beta/tau cascade. Sci. Transl. Med. 2020,12. [CrossRef]

96. Baek, M.S.; Cho, H.; Lee, H.S.; Choi, J.Y.; Lee, J.H.; Ryu, Y.H.; Lee, M.S.; Lyoo, C.H. Temporal trajectories of in vivo tau and amyloid-beta accumulation in Alzheimer's disease. Eur. J. Nucl. Med. Mol. Imaging 2020. [CrossRef]

97. Liu, P.; Reed, M.N.; Kotilinek, L.A.; Grant, M.K.O.; Forster, C.L.; Qiang, W.; Shapiro, S.L.; Reichl, J.H.; Chiang, A.C.A.; Jankowsky, J.L.; et al. Quaternary Structure Defines a Large Class of Amyloid-beta Oligomers Neutralized by Sequestration. Cell Rep. 2015, 11, 1760-1771. [CrossRef]

98. Wang, T.; Xie, X.X.; Ji, M.; Wang, S.W.; Zha, J.; Zhou, W.W.; Yu, X.L.; Wei, C.; Ma, S.; Xi, Z.Y.; et al. Naturally occurring autoantibodies against A beta oligomers exhibited more beneficial effects in the treatment of mouse model of Alzheimer's disease than intravenous immunoglobulin. Neuropharmacology 2016, 105, 561-576. [CrossRef]

99. Zhang, X.; Sun, X.-X.; Xue, D.; Liu, D.-G.; Hu, X.-Y.; Zhao, M.; Yang, S.-G.; Yang, Y.; Xia, Y.-J.; Wang, Y.; et al. Conformation-dependent $\mathrm{scFv}$ antibodies specifically recognize the oligomers assembled from various amyloids and show colocalization of amyloid fibrils with oligomers in patients with amyloidoses. Biochim. Et Biophys. Acta BBA Proteins Proteom. 2011, 1814, 1703-1712. [CrossRef]

100. Zhao, M.; Wang, S.W.; Wang, Y.J.; Zhang, R.; Li, Y.N.; Su, Y.J.; Zhou, W.W.; Yu, X.L.; Liu, R.T. Pan-amyloid oligomer specific scFv antibody attenuates memory deficits and brain amyloid burden in mice with Alzheimer's disease. Curr. Alzheimer Res. 2014, 11, 69-78. [CrossRef]

101. Brinkmalm, G.; Hong, W.; Wang, Z.; Liu, W.; O’Malley, T.T.; Sun, X.; Frosch, M.P.; Selkoe, D.J.; Portelius, E.; Zetterberg, H.; et al. Identification of neurotoxic cross-linked amyloid-beta dimers in the Alzheimer's brain. Brain 2019, 142, 1441-1457. [CrossRef] [PubMed]

102. Jin, M.; Shepardson, N.; Yang, T.; Chen, G.; Walsh, D.; Selkoe, D.J. Soluble amyloid beta-protein dimers isolated from Alzheimer cortex directly induce Tau hyperphosphorylation and neuritic degeneration. Proc. Natl. Acad. Sci. USA 2011, 108, 5819-5824. [CrossRef] [PubMed]

103. Abdel-Hafiz, L.; Muller-Schiffmann, A.; Korth, C.; Fazari, B.; Chao, O.Y.; Nikolaus, S.; Schable, S.; Herring, A.; Keyvani, K.; Lamounier-Zepter, V.; et al. Abeta dimers induce behavioral and neurochemical deficits of relevance to early Alzheimer's disease. Neurobiol. Aging 2018, 69, 1-9. [CrossRef] [PubMed]

104. Zott, B.; Simon, M.M.; Hong, W.; Unger, F.; Chen-Engerer, H.J.; Frosch, M.P.; Sakmann, B.; Walsh, D.M.; Konnerth, A. A vicious cycle of beta amyloid-dependent neuronal hyperactivation. Science 2019, 365, 559-565. [CrossRef] [PubMed]

105. Jana, M.K.; Cappai, R.; Pham, C.L.; Ciccotosto, G.D. Membrane-bound tetramer and trimer Abeta oligomeric species correlate with toxicity towards cultured neurons. J. Neurochem. 2016, 136, 594-608. [CrossRef]

106. Crouch, P.J.; Hung, L.W.; Adlard, P.A.; Cortes, M.; Lal, V.; Filiz, G.; Perez, K.A.; Nurjono, M.; Caragounis, A.; $\mathrm{Du}, \mathrm{T}$; ; et al. Increasing $\mathrm{Cu}$ bioavailability inhibits Abeta oligomers and tau phosphorylation. Proc. Natl. Acad. Sci. USA 2009, 106, 381-386. [CrossRef]

107. Sherman, M.A.; LaCroix, M.; Amar, F.; Larson, M.E.; Forster, C.; Aguzzi, A.; Bennett, D.A.; Ramsden, M.; Lesne, S.E. Soluble Conformers of Abeta and Tau Alter Selective Proteins Governing Axonal Transport. J. Neurosci. 2016, 36, 9647-9658. [CrossRef]

108. Townsend, M.; Shankar, G.M.; Mehta, T.; Walsh, D.M.; Selkoe, D.J. Effects of secreted oligomers of amyloid beta-protein on hippocampal synaptic plasticity: A potent role for trimers. J. Physiol 2006, 572, 477-492. [CrossRef] 
109. Lesne, S.; Koh, M.T.; Kotilinek, L.; Kayed, R.; Glabe, C.G.; Yang, A.; Gallagher, M.; Ashe, K.H. A specific amyloid-beta protein assembly in the brain impairs memory. Nature 2006, 440, 352-357. [CrossRef]

110. Lesne, S.E.; Sherman, M.A.; Grant, M.; Kuskowski, M.; Schneider, J.A.; Bennett, D.A.; Ashe, K.H. Brain amyloid-beta oligomers in ageing and Alzheimer's disease. Brain 2013, 136, 1383-1398. [CrossRef]

111. Amar, F.; Sherman, M.A.; Rush, T.; Larson, M.; Boyle, G.; Chang, L.; Gotz, J.; Buisson, A.; Lesne, S.E. The amyloid-beta oligomer Abeta*56 induces specific alterations in neuronal signaling that lead to tau phosphorylation and aggregation. Sci. Signal. 2017, 10. [CrossRef] [PubMed]

112. Thibaudeau, T.A.; Anderson, R.T.; Smith, D.M. A common mechanism of proteasome impairment by neurodegenerative disease-associated oligomers. Nat. Commun. 2018, 9, 1097. [CrossRef] [PubMed]

113. Barghorn, S.; Nimmrich, V.; Striebinger, A.; Krantz, C.; Keller, P.; Janson, B.; Bahr, M.; Schmidt, M.; Bitner, R.S.; Harlan, J.; et al. Globular amyloid beta-peptide oligomer-A homogenous and stable neuropathological protein in Alzheimer's disease. J. Neurochem. 2005, 95, 834-847. [CrossRef] [PubMed]

114. Ohnishi, T.; Yanazawa, M.; Sasahara, T.; Kitamura, Y.; Hiroaki, H.; Fukazawa, Y.; Kii, I.; Nishiyama, T.; Kakita, A.; Takeda, H.; et al. Na, K-ATPase alpha3 is a death target of Alzheimer patient amyloid-beta assembly. Proc. Natl. Acad. Sci. USA 2015, 112, E4465-E4474. [CrossRef]

115. Wen, J.; Fang, F.; Guo, S.H.; Zhang, Y.; Peng, X.L.; Sun, W.M.; Wei, X.R.; He, J.S.; Hung, T. Amyloid beta-Derived Diffusible Ligands (ADDLs) Induce Abnormal Autophagy Associated with Abeta Aggregation Degree. J. Mol. Neurosci. 2018, 64, 162-174. [CrossRef] [PubMed]

116. Liu, X.; Teng, Z.; Cui, C.; Wang, R.; Liu, M.; Zhang, Y. Amyloid beta-derived diffusible ligands (ADDLs) induce abnormal expression of insulin receptors in rat hippocampal neurons. J. Mol. Neurosci. 2014, 52, 124-130. [CrossRef]

117. Herzer, S.; Meldner, S.; Rehder, K.; Grone, H.J.; Nordstrom, V. Lipid microdomain modification sustains neuronal viability in models of Alzheimer's disease. Acta Neuropathol. Commun. 2016, 4, 103. [CrossRef]

118. Shi, X.D.; Sun, K.; Hu, R.; Liu, X.Y.; Hu, Q.M.; Sun, X.Y.; Yao, B.; Sun, N.; Hao, J.R.; Wei, P.; et al. Blocking the Interaction between EphB2 and ADDLs by a Small Peptide Rescues Impaired Synaptic Plasticity and Memory Deficits in a Mouse Model of Alzheimer's Disease. J. Neurosci. 2016, 36, 11959-11973. [CrossRef]

119. Zempel, H.; Thies, E.; Mandelkow, E.; Mandelkow, E.M. Abeta oligomers cause localized Ca(2+) elevation, missorting of endogenous Tau into dendrites, Tau phosphorylation, and destruction of microtubules and spines. J. Neurosci. 2010, 30, 11938-11950. [CrossRef]

120. Roberson, E.D.; Halabisky, B.; Yoo, J.W.; Yao, J.; Chin, J.; Yan, F.; Wu, T.; Hamto, P.; Devidze, N.; Yu, G.Q.; et al. Amyloid-beta/Fyn-induced synaptic, network, and cognitive impairments depend on tau levels in multiple mouse models of Alzheimer's disease. J. Neurosci. 2011, 31, 700-711. [CrossRef]

121. Mc Donald, J.M.; Savva, G.M.; Brayne, C.; Welzel, A.T.; Forster, G.; Shankar, G.M.; Selkoe, D.J.; Ince, P.G.; Walsh, D.M.; on behalf of the Medical Research Council Cognitive Function and Ageing Study. The presence of sodium dodecyl sulphate-stable Abeta dimers is strongly associated with Alzheimer-type dementia. Brain 2010, 133, 1328-1341. [CrossRef] [PubMed]

122. Mc Donald, J.M.; O’Malley, T.T.; Liu, W.; Mably, A.J.; Brinkmalm, G.; Portelius, E.; Wittbold, W.M., 3rd; Frosch, M.P.; Walsh, D.M. The aqueous phase of Alzheimer's disease brain contains assemblies built from approximately 4 and approximately 7 kDa Abeta species. Alzheimers Dement. 2015, 11, 1286-1305. [CrossRef] [PubMed]

123. Kawarabayashi, T.; Shoji, M.; Younkin, L.H.; Wen-Lang, L.; Dickson, D.W.; Murakami, T.; Matsubara, E.; Abe, K.; Ashe, K.H.; Younkin, S.G. Dimeric amyloid beta protein rapidly accumulates in lipid rafts followed by apolipoprotein E and phosphorylated tau accumulation in the Tg2576 mouse model of Alzheimer's disease. J. Neurosci. 2004, 24, 3801-3809. [CrossRef] [PubMed]

124. Shankar, G.M.; Leissring, M.A.; Adame, A.; Sun, X.; Spooner, E.; Masliah, E.; Selkoe, D.J.; Lemere, C.A.; Walsh, D.M. Biochemical and immunohistochemical analysis of an Alzheimer's disease mouse model reveals the presence of multiple cerebral Abeta assembly forms throughout life. Neurobiol. Dis. 2009, 36, $293-302$. [CrossRef] [PubMed]

125. Vazquez de la Torre, A.; Gay, M.; Vilaprinyo-Pascual, S.; Mazzucato, R.; Serra-Batiste, M.; Vilaseca, M.; Carulla, N. Direct Evidence of the Presence of Cross-Linked Abeta Dimers in the Brains of Alzheimer's Disease Patients. Anal. Chem. 2018, 90, 4552-4560. [CrossRef] [PubMed]

126. O'Malley, T.T.; Witbold, W.M., 3rd; Linse, S.; Walsh, D.M. The Aggregation Paths and Products of Abeta42 Dimers Are Distinct from Those of the Abeta42 Monomer. Biochemistry 2016, 55, 6150-6161. [CrossRef] 
127. Meilandt, W.J.; Cisse, M.; Ho, K.; Wu, T.; Esposito, L.A.; Scearce-Levie, K.; Cheng, I.H.; Yu, G.Q.; Mucke, L. Neprilysin overexpression inhibits plaque formation but fails to reduce pathogenic Abeta oligomers and associated cognitive deficits in human amyloid precursor protein transgenic mice. J. Neurosci. 2009, 29, 1977-1986. [CrossRef]

128. Kreutzer, A.G.; Yoo, S.; Spencer, R.K.; Nowick, J.S. Stabilization, Assembly, and Toxicity of Trimers Derived from Abeta. J. Am. Chem. Soc. 2017, 139, 966-975. [CrossRef]

129. Reed, M.N.; Hofmeister, J.J.; Jungbauer, L.; Welzel, A.T.; Yu, C.; Sherman, M.A.; Lesne, S.; LaDu, M.J.; Walsh, D.M.; Ashe, K.H.; et al. Cognitive effects of cell-derived and synthetically derived Abeta oligomers. Neurobiol. Aging 2011, 32, 1784-1794. [CrossRef]

130. Cheng, I.H.; Scearce-Levie, K.; Legleiter, J.; Palop, J.J.; Gerstein, H.; Bien-Ly, N.; Puolivali, J.; Lesne, S.; Ashe, K.H.; Muchowski, P.J.; et al. Accelerating amyloid-beta fibrillization reduces oligomer levels and functional deficits in Alzheimer disease mouse models. J. Biol. Chem. 2007, 282, 23818-23828. [CrossRef]

131. Oddo, S.; Caccamo, A.; Tran, L.; Lambert, M.P.; Glabe, C.G.; Klein, W.L.; LaFerla, F.M. Temporal profile of amyloid-beta (Abeta) oligomerization in an in vivo model of Alzheimer disease. A link between Abeta and tau pathology. J. Biol. Chem. 2006, 281, 1599-1604. [CrossRef] [PubMed]

132. Yoo, S.J.; Lee, J.H.; Kim, S.Y.; Son, G.; Kim, J.Y.; Cho, B.; Yu, S.W.; Chang, K.A.; Suh, Y.H.; Moon, C. Differential spatial expression of peripheral olfactory neuron-derived BACE1 induces olfactory impairment by region-specific accumulation of beta-amyloid oligomer. Cell Death Dis. 2017, 8, e2977. [CrossRef] [PubMed]

133. Hoshi, M.; Sato, M.; Matsumoto, S.; Noguchi, A.; Yasutake, K.; Yoshida, N.; Sato, K. Spherical aggregates of beta-amyloid (amylospheroid) show high neurotoxicity and activate tau protein kinase I/glycogen synthase kinase-3beta. Proc. Natl. Acad. Sci. USA 2003, 100, 6370-6375. [CrossRef]

134. Parthasarathy, S.; Inoue, M.; Xiao, Y.; Matsumura, Y.; Nabeshima, Y.; Hoshi, M.; Ishii, Y. Structural Insight into an Alzheimer's Brain-Derived Spherical Assembly of Amyloid beta by Solid-State NMR. J. Am. Chem. Soc. 2015, 137, 6480-6483. [CrossRef] [PubMed]

135. Noguchi, A.; Matsumura, S.; Dezawa, M.; Tada, M.; Yanazawa, M.; Ito, A.; Akioka, M.; Kikuchi, S.; Sato, M.; Ideno, S.; et al. Isolation and characterization of patient-derived, toxic, high mass amyloid beta-protein (Abeta) assembly from Alzheimer disease brains. J. Biol. Chem. 2009, 284, 32895-32905. [CrossRef]

136. Komura, H.; Kakio, S.; Sasahara, T.; Arai, Y.; Takino, N.; Sato, M.; Satomura, K.; Ohnishi, T.; Nabeshima, Y.I.; Muramatsu, S.I.; et al. Alzheimer Abeta Assemblies Accumulate in Excitatory Neurons upon Proteasome Inhibition and Kill Nearby NAKalpha3 Neurons by Secretion. iScience 2019, 13, 452-477. [CrossRef]

137. Gong, Y.; Chang, L.; Viola, K.L.; Lacor, P.N.; Lambert, M.P.; Finch, C.E.; Krafft, G.A.; Klein, W.L. Alzheimer's disease-affected brain: Presence of oligomeric A beta ligands (ADDLs) suggests a molecular basis for reversible memory loss. Proc. Natl. Acad. Sci. USA 2003, 100, 10417-10422. [CrossRef]

138. Chang, L.; Bakhos, L.; Wang, Z.; Venton, D.L.; Klein, W.L. Femtomole immunodetection of synthetic and endogenous amyloid-beta oligomers and its application to Alzheimer's disease drug candidate screening. J. Mol. Neurosci. 2003, 20, 305-313. [CrossRef]

139. Lambert, M.P.; Velasco, P.T.; Chang, L.; Viola, K.L.; Fernandez, S.; Lacor, P.N.; Khuon, D.; Gong, Y.S.; Bigio, E.H.; Shaw, P.; et al. Monoclonal antibodies that target pathological assemblies of A beta. J. Neurochem. 2007, 100, 23-35. [CrossRef]

140. Xie, Z.; Shapiro, L.P.; Cahill, M.E.; Russell, T.A.; Lacor, P.N.; Klein, W.L.; Penzes, P. Kalirin-7 prevents dendritic spine dysgenesis induced by amyloid beta-derived oligomers. Eur. J. Neurosci. 2019, 49, 1091-1101. [CrossRef]

141. Henley, D.; Raghavan, N.; Sperling, R.; Aisen, P.; Raman, R.; Romano, G. Preliminary Results of a Trial of Atabecestat in Preclinical Alzheimer's Disease. N. Engl. J. Med. 2019, 380, 1483-1485. [CrossRef] [PubMed]

142. Doody, R.S.; Raman, R.; Farlow, M.; Iwatsubo, T.; Vellas, B.; Joffe, S.; Kieburtz, K.; He, F.; Sun, X.Y.; Thomas, R.G.; et al. A Phase 3 Trial of Semagacestat for Treatment of Alzheimer's Disease. N. Engl. J. Med. 2013, 369, 341-350. [CrossRef] [PubMed]

143. Salloway, S.; Sperling, R.; Fox, N.C.; Blennow, K.; Klunk, W.; Raskind, M.; Sabbagh, M.; Honig, L.S.; Porsteinsson, A.P.; Ferris, S.; et al. Two Phase 3 Trials of Bapineuzumab in Mild-to-Moderate Alzheimer's Disease. N. Engl. J. Med. 2014, 370, 322-333. [CrossRef] [PubMed] 
144. Honig, L.S.; Vellas, B.; Woodward, M.; Boada, M.; Bullock, R.; Borrie, M.; Hager, K.; Andreasen, N.; Scarpini, E.; Liu-Seifert, H.; et al. Trial of Solanezumab for Mild Dementia Due to Alzheimer's Disease. New Engl. J. Med. 2018, 378, 321-330. [CrossRef] [PubMed]

145. Nicoll, J.A.R.; Buckland, G.R.; Harrison, C.H.; Page, A.; Harris, S.; Love, S.; Neal, J.W.; Holmes, C.; Boche, D. Persistent neuropathological effects 14 years following amyloid-beta immunization in Alzheimer's disease. Brain 2019, 142, 2113-2126. [CrossRef]

(C) 2020 by the authors. Licensee MDPI, Basel, Switzerland. This article is an open access article distributed under the terms and conditions of the Creative Commons Attribution (CC BY) license (http://creativecommons.org/licenses/by/4.0/). 